\title{
Prevalência de sedentarismo, excesso de peso e insatisfação com a imagem corporal em adolescentes de Florianópolis, SC
}

\author{
Prevalence of sedentary lifestyle, overweight and body image \\ dissatisfaction among adolescents from Florianópolis, SC
}

Andreia Pelegrini 1

Resumo - Objetivo: Analisar a prevalência de sedentarismo, excesso de peso e insatisfação com a imagem corporal em adolescentes bem como os fatores associados. Métodos: Estudo transversal realizado com amostra representativa de adolescentes de 14 a 18 anos, matriculados no ensino médio, da rede pública de Florianópolis, SC. Foram coletadas informações sociodemográficas (sexo, idade, nível socioeconômico), antropométricas (massa corporal, estatura), percepção da imagem corporal (silhuetas real e ideal) e nível de atividade física (sedentarismo: < 300 minutos/semana). Resultados: A prevalência de sedentarismo foi de 25,4\% (masculino: 21,9\%; feminino: 27,1\%, $\mathrm{p}=0,177$ ). No sexo feminino, encontrou-se que as adolescentes com baixo peso e aquelas que permanecem mais de 4 horas assistindo a televisão apresentaram, respectivamente, 2,69 e 2,25 vezes mais chance de serem sedentárias. A prevalência de excesso de peso foi de 13,9\% (masculino: 13,6\%; feminino: $14,1 \%, p=0,860$ ). Houve associação entre o excesso de peso e o nível socioeconômico, cujos adolescentes de condição econômica mais elevada (classe A) demonstraram 2,7 vezes mais chances de apresentarem excesso de peso em relação aos de baixo nível econômico $(\mathrm{C}+\mathrm{D}+\mathrm{E})$. A proporção de adolescentes insatisfeitos com a imagem corporal foi de 65,5\% (masculino: $72,6 \%$; feminino: $61,8 \%, p<0,001)$. Os resultados demonstraram ainda que 48,4\% dos adolescentes do sexo feminino e $51,3 \%$ dos adolescentes do sexo masculino desejavam reduzir e aumentar a silhueta corporal, respectivamente. O IMC inadequado associou-se à insatisfação com a imagem corporal apenas nas moças (IC95\%=1,35-3,43). As moças com excesso de peso apresentaram 11 vezes mais chances de insatisfação com a imagem corporal que as eutróficas. Conclusão: $O$ sedentarismo em adolescentes é preocupante, pois atinge um em cada quatro adolescentes, neste sentido, sugere-se programas de atividade física nesta fase da vida. Em relação ao excesso de peso, atenção deve ser dada aos adolescentes, voltadas à orientação nutricional e atividade física, principalmente naqueles de elevado nível econômico. O estado nutricional foi um fator determinante na insatisfação corporal, principalmente, nas adolescentes do sexo feminino, pois àquelas com inadequação do estado nutricional apresentaram níveis de insatisfação diferentes daquelas com IMC adequado.

Palavras-chave: Antropometria; Estado nutricional; Estudantes; Imagem corporal; Atividade física.

Abstract - Objective: Analyze the prevalence of sedentarism lifestyle, overweight and body image dissatisfaction among adolescents and the factors associated with these variables. Methods: This was a cross-sectional study of a representative sample of adolescents aged 14 to 18 years, enrolled in public sector Secondary Education in Florianópolis, SC, Brazil. The following data were recorded: sociodemographic (gender, age, socioeconomic status), anthropometric (body weight, height), perception of body image (real and ideal silhouettes) and level of physical activity (sedentarism lifestyle: $<300$ minutes/week). Results: The prevalence of sedentarism lifestyle was 25.4\% (male: 21.9\%; female: $27.1 \%, p=0.177)$. Among the females, it was found that low weight adolescents and those who spend more than 4 hours/day watching television had 2.69 and 2.25 times greater chance of being sedentary respectively. The prevalence of overweight was $13.9 \%$ (male: $13.6 \%$; female: $14.1 \%, p=0.860$ ). There was an association between overweight and socioeconomic status, where adolescents living in better economic conditions (class A) demonstrated a 2.7 times greater chance of being overweight with relation to lower economic classes $(C+D+E)$. The proportion of adolescents unsatisfied with body image was $65.5 \%$ (male: $72.6 \%$; female: $61.8 \%, p<0.001$ ). The results also demonstrated that $48.4 \%$ of the female adolescents and $51.3 \%$ of the male adolescents wished to reduce or increase their body silhouettes, respectively. Unhealthy BMI was associated with body image dissatisfaction only among the girls $(95 \% \mathrm{CI} \%=1.35-3.43)$. Overweight girls exhibited 11 times greater chances of body image dissatisfaction than those with healthy BMI

1 Universidade Federal de Santa Catarina. Centro de Desportos. Mestrado em Educação Física. Florianópolis, SC. Brasil. 2008.

Orientador: Prof. Dr. Edio Luiz Petroski.
Conclusion: The sedentarism lifestyle among adolescents is worrying, since it affects one in every four adolescents. For this reason, physical activity programs are recommended during this stage of life. With relation to overweight, interventions with adolescents, particularly those from higher socioeconomic levels, should include nutritional guidance and encourage physical activity. Nutritional status was a decisive factor in body dissatisfaction, primarily among female adolescents, since those with unhealthy nutritional status had higher levels of dissatisfaction than those with healthy BMI.

Key words: Anthropometry; Nutritional status; Students; Body image; Physical activity. 